\title{
Physical Activity in Breast Cancer Patients during Medical Treatment and in the Aftercare - a Review
}

\author{
Freerk T. Baumann Wilhelm Bloch Anke Weissen Marie Brockhaus \\ Julia Beulertz Philipp Zimmer Fiona Streckmann Eva M. Zopf
}

Department of Molecular and Cellular Sport Medicine, German Sport University Cologne, Germany

\section{Keywords}

Physical activity · Exercise · Breast cancer

\section{Summary}

Most scientific studies regarding physical activity in cancer patients involve breast cancer patients. It is apparent that physical activity during medical treatment and aftercare is not only feasible and safe but also effective. Current studies clearly show that regular and specific endurance and/or resistance training can reduce a number of side effects caused by medical treatment. Among others, improvements in physical performance, body composition, and quality of life as well as a reduction in fatigue, have been observed. Since inactivity appears to exacerbate lymphedema, patients with lymphedema are also encouraged to exercise. Few studies have been carried out regarding physical exercise in metastatic patients. However, experts in the field also recommend regular physical activity for patients with advanced-stage breast cancer.

\section{Introduction}

Despite the increasing incidence rate, the chance of cure from breast cancer has improved due to advanced medical treatment options [1]. However, these improved treatment options cause considerable side effects on different levels. Physical symptoms include reduced muscle strength and bone mineral density, impaired range of motion in the arm and shoulder region, hot flushes, and lymphedemas [2]. Depression, anxiety, and reduced self-esteem and self-confidence are commonly experienced on the psychological level. Further,

\author{
Schlüsselwörter \\ Körperliche Aktivität · Sport · Mammakarzinom
}

\section{Zusammenfassung}

Die meisten wissenschaftlichen Untersuchungen zu körperlicher Aktivität bei Krebs wurden mit Brustkrebspatientinnen durchgeführt. Es zeigt sich, dass körperliche Aktivität während der medizinischen Therapie und in der Nachsorge nicht nur machbar und sicher, sondern auch effektiv ist. Die Datenlage zeigt deutlich, dass ein regelmäßiges und gezieltes Ausdauerund/oder Krafttraining spezifische Nebenwirkungen der medizinischen Therapie reduzieren kann. Dazu zählen die Verbesserung der körperlichen Leistungsfähigkeit und Körperkomposition, Reduktion von Fatigue und die Verbesserung/Stabilisierung der Lebensqualität. Auch Patientinnen mit einem Lymphödem sollten sich körperlich betätigen. Es scheint, dass körperliche Inaktivität zur Verschlimmerung des Ödems beiträgt. Zu körperlicher Aktivität von Patientinnen mit Metastasen gibt es bislang kaum Studien. Dennoch wird auch bei diesen Patientinnen nach Expertenmeinung regelmäßige Bewegung empfohlen.

decreased physical activity levels and other social impairments, such as reduced participation in social and leisure activities, as well as relationship and employment problems may appear [3,4]. All of these extensive adverse effects of treatment impact breast cancer patients' quality of life [5]. Therefore, it is important to counteract or reduce these side effects by offering specific supportive programs and lead the patient back to her familiar surroundings, daily routine, and family life as quickly as possible [6]. Physical activity can be such a supportive measure.

\section{KARGER \\ Fax +497614520714 \\ Information@Karger.com}

www.karger.com
(C) 2013 S. Karger GmbH, Freiburg

$1661-3791 / 13 / 0085-0330 \$ 38.00 / 0$

Accessible online at:

www.karger.com/brc 


\section{Rationale and Aim of the Review}

The basic objective of exercise therapy in breast cancer patients is to reduce treatment-related side effects and positively influence the patients' quality of life. Physical activities during medical breast cancer treatment as well as during aftercare have been proven to be feasible, safe, and effective [7, 8]. However, aside from the breast cancer itself and its consequences, 2 relevant aspects have to be considered when planning an exercise intervention: i) medical treatment and its side effects; and ii) the individual background of each patient. This holistic approach allows us to expect an effect on the patient's physical, psychological, social, and educative level [9]. This clinical review aims to summarize the current literature on physical activity in breast cancer patients during/after medical treatment. Next to well-known parameters such as physical performance, fatigue, and quality of life, this review focuses on outcomes that have recently been studied, such as lymphedema, metastases, and mortality risk. Based on the results, clinical guidelines will be defined.

\section{Physical Activity during Medical Treatment}

To our knowledge, the first study examining the influence of physical activity during chemotherapy was conducted in 1988 with 42 breast cancer patients. Endurance training on a bicycle ergometer positively influenced nausea in the patients [10]. Winningham et al. continued the research and detected further significant positive effects regarding physical performance, body composition, and body weight in 2 randomized controlled trials (RCTs) with patients undergoing chemotherapy [11]. More than 10 years later, first studies also showed positive effects in breast cancer patients receiving radiation. Mock et al., for example, observed that women who exercised less than 90 min per week within a moderate walking program experienced clearly higher levels of fatigue during radiation [12]. In the meantime, numerous other RCTs confirmed the positive effect of physical exercise on the fatigue syndrome occurring during medical treatment $[13,14]$. What remains uncertain is evidence concerning specific modes and dosages of exercise; however, in principle, strength and endurance training seem to have a similar effect on fatigue [8].

The effect of therapeutic exercise on patients' physical performance has also been proven in many studies. Both resistance and endurance training during medical treatment can improve or at least stabilize physical performance $[13,15$, 16]. Furthermore, endurance training can reduce the resting heart rate and blood pressure in breast cancer patients [17]. Regarding body composition, it remains uncertain whether endurance training or resistance training has a greater impact; however, a positive effect can be observed [11]. Resistance training may be more effective when aiming to prevent weight loss in patients undergoing treatment [15]. Further studies show that a combined training program composed of endurance, resistance, coordinative, and stretching components can positively influence flexibility, pain, and energy consumption in breast cancer patients $[14,16,18]$.

Current studies suggest that moderate endurance training during medical treatment can also improve psychological symptoms, such as depression and low self-esteem, in breast cancer patients $[12,13,15,19]$. In addition, Payne et al. were able to show that sleep disturbance and serotonin levels can be influenced by a walking exercise intervention in patients receiving hormonal treatment [21]. The holistic effects of physical exercise positively influence quality of life $[13,15,16]$.

\section{Physical Activity during Aftercare}

Therapeutic exercise interventions during survivorship have proven to increase physical activity levels in breast cancer patients $[22,23]$. Both aerobic endurance training over 12 weeks and combined resistance and endurance training over 6 months can positively influence the cardiovascular fitness of breast cancer patients during aftercare [22, 24]. Improvements in muscle strength have been observed primarily in studies conducting either resistance training alone or a combination of resistance and endurance training [24, 25]. In addition, first studies show that combined programs, such as controlled impact and resistance training, may counteract osteoporosis [26]. Regarding shoulder flexibility, breast cancer patients may benefit more from Nordic walking than from a normal walking program [27]. Both endurance and resistance training programs during aftercare of breast cancer treatment have shown positive effects on fatigue and quality of life [22]. Aside from endurance and resistance interventions, an increasing number of studies are also investigating the effects of dancing, yoga, and Tai Chi in breast cancer patients, and have observed physical and psychological improvements [28].

\section{Physical Activity and Mortality Risk}

Aside from the positive influence on adverse effects, preliminary evidence suggests that physical activity can influence the overall and breast cancer-specific mortality risk as well as the risk of recurrence in breast cancer patients. A meta-analysis by Ibrahim et al. showed that regular physical activity prior to diagnosis does not affect breast cancer-specific mortality [29]. However, physical activity after diagnosis reduces breast cancer-specific mortality by $34 \%$ and overall mortality by $41 \%$. These findings are supported by further studies by Beasley et al., Cadmus et al., Friedenreich et al., Holmes et al., and West-Wright et al. [30-34]. Furthermore, a meta-analysis by Loprinzi et al. revealed significant indications regarding 
Table 1. Specific recommendations for physical exercise in breast cancer patients in relation to lymphedema, metastases, and recurrence prevention

\begin{tabular}{|c|c|c|c|c|c|}
\hline & \multirow{2}{*}{$\begin{array}{l}\text { Lymphedema } \\
\text { [36-39] }\end{array}$} & \multicolumn{3}{|c|}{ Metastases [7, 8, 40-42, expert opinion] } & \multirow{2}{*}{$\begin{array}{l}\text { Preventing } \\
\text { recurrence [29-35] }\end{array}$} \\
\hline & & bone & lung and liver & brain & \\
\hline $\begin{array}{l}\text { Duration of the } \\
\text { intervention }\end{array}$ & $\begin{array}{l}8-12 \text { week resistance } \\
\text { training, eventually } \\
\text { preferred exercise } \\
\text { mode }\end{array}$ & permanent & permanent & permanent & permanent \\
\hline Exercise mode & $\begin{array}{l}\text { physical exercises, } \\
\text { also including the } \\
\text { arms }\end{array}$ & $\begin{array}{l}\text { patients at low risk } \\
\text { of bone fracture: } \\
\text { endurance training, } \\
\text { light resistance training; } \\
\text { patients at high risk of } \\
\text { bone fracture: aquatic } \\
\text { exercises/swimming, } \\
\text { endurance training }\end{array}$ & $\begin{array}{l}\text { light resistance training } \\
\text { and moderate endurance } \\
\text { training }\end{array}$ & $\begin{array}{l}\text { individual training } \\
\text { depending on } \\
\text { symptoms and } \\
\text { impairments, e.g. } \\
\text { coordinative or } \\
\text { cognitive exercises }\end{array}$ & $\begin{array}{l}\text { physical activities } \\
\text { in general, no } \\
\text { specific method }\end{array}$ \\
\hline Intensity & $\begin{array}{l}\text { begin with short and } \\
\text { light exercises and } \\
\text { feel the effect; if } \\
\text { lymphedema does not } \\
\text { exacerbate, intensities } \\
\text { can be increased } \\
\text { progressively }\end{array}$ & light to moderate & $\begin{array}{l}\text { optimal intensity is } \\
\text { dependent on the } \\
\text { degree of metastasis/ } \\
\text { secondary tumors; } \\
\text { more pronounced } \\
\text { stage: only moderate } \\
\text { and slightly strenuous } \\
\text { intensities }\end{array}$ & light to moderate & \\
\hline Recommendation & $\begin{array}{l}\text { What reduces or } \\
\text { exacerbates an } \\
\text { edema may vary! } \\
\text { First, patients need } \\
\text { to reexamine } \\
\text { themselves to find } \\
\text { out what exercises } \\
\text { they benefit from. } \\
\text { Patients should } \\
\text { approach the } \\
\text { exercises slowly. }\end{array}$ & $\begin{array}{l}\text { patients at low risk of } \\
\text { bone fracture: jogging, } \\
\text { (Nordic) walking, cycling, } \\
\text { light resistance training; } \\
\text { patients at low risk of } \\
\text { bone fracture : aquatic } \\
\text { exercises/swimming, } \\
\text { (Nordic) walking; } \\
\text { avoid: activities with } \\
\text { a high risk of falling or } \\
\text { injury and high impact/ } \\
\text { load peaks at frequent } \\
\text { intervals }\end{array}$ & $\begin{array}{l}\text { by strengthening the } \\
\text { respiratory and trunk } \\
\text { muscles respiratory } \\
\text { capacity can be } \\
\text { influenced in an } \\
\text { optimal manner }\end{array}$ & $\begin{array}{l}\text { propensity for } \\
\text { seizure: increased } \\
\text { risk of injury; } \\
\text { avoid swimming } \\
\text { or aquatic exercises, } \\
\text { avoid overhasty } \\
\text { movements }\end{array}$ & $\begin{array}{l}3-5 \text { h of physical } \\
\text { exercise per week; } \\
10 \mathrm{MET} / \mathrm{h} \\
\text { per week with } \\
4 \mathrm{MET} / \mathrm{h} \text { per } \\
\text { session; moderate } \\
\text { intensity }\end{array}$ \\
\hline
\end{tabular}

the positive effect of physical exercise on the risk of breast cancer recurrence [35] (table 1).

\section{Physical Activity and Lymphedema}

Physical activity seems to have a positive influence on the symptoms of lymphedema [36-38]. Studies have shown that upper body exercises do not lead to significant changes in arm volume, not even in patients that have already developed a lymphedema [36-37]. Moreover, physical inactivity or resting can clearly contribute to a worsening of lymphedema among patients at risk [37]. Water therapy seems to have the best effects on the symptoms of lymphedema [38]. In primary prevention, physical exercise is probably not a risk factor for developing lymphedema either [39] (table 1).

\section{Physical Activity and Metastases}

The current evidence regarding physical activity in patients with advanced breast cancer is weak. Only few studies with different cancer types, breast cancer among others, have investigated the effect of exercise on fatigue, psychological stress, somatic complaints, and anxiety. However, a positive influence on these outcomes could be detected [40, 41]. A reduction in fatigue was observed in an RCT with 38 metastatic breast cancer patients receiving chemotherapy. Patients took part in a home-based resistance training program where resistance exercises were conducted in a sitting position [40]. A number of case reports examined the effects of exercising in women with bone metastases and found that physical training can be feasible, safe, and performance-enhancing [42]. Current exercise recommendations are based on expert opinion (table 1).

\section{Discussion}

Physical activity in breast cancer patients during medical treatment and aftercare is feasible, safe, and effective [8]. Numerous studies have investigated the impact of therapeutic exercise on the adverse effects of adjuvant treatment. Findings are extensive and positive [43]. Current research focuses on aerobic fitness, muscle strength, quality of life, fatigue, and body composition. Evidence regarding the influence of physical activity on these outcomes is consistent and good. Exercise studies showing positive effects on immune function, flexibil- 
ity, and bone mineral density also exist; however, the evidence is comparatively weak and needs to be supported by further investigations. This also applies to studies regarding the effect of therapeutic exercise interventions on psychological outcomes. Current studies in this field of research show wide variations in quality, assessment methods, and exercise intensity and volume; for example, on average, patients exercise approximately 3 times per week for 20-50 min with moderate intensity and varying modes of exercise. Most of the interventions last for 12-24 weeks [7, 8, 44].

This clinical review specifically focused on current research outcomes such as lymphedema, mortality, and metastasis. Another question that will need clarification is whether physical activity can reduce the risk of recurrence in breast cancer patients. A number of observational studies have suggested a positive effect of physical activity with a reduced risk of recurrence of $30 \%$ [29]. However, randomized and controlled intervention studies are still missing. Therefore, the evidence is weak in this field of research, in contrast to research results in primary prevention.

Various potential mechanistic aspects that may reduce the risk of recurrence in breast cancer patients are being discussed. On an immunological level, different cytokines as well as a change in natural killer cell activation are taken into consideration [45, 46]. Also, hormonal changes such as a reduction in estrogen and progesterone levels may have a specific influence [47]. Additionally, an improved balance between oxidative stress and anti-oxidative capacity must be considered [48]. Future studies must therefore focus on these potential underlying mechanisms. What seems to have proven true is that physical exercise does not contribute to the exacerbation or onset of lymphedema [39]. On the contrary, an increasing number of findings show that physical inactivity or rest can worsen the symptoms of lymphedema [36, 37]. A positive effect on the lymphatic backflow may be achieved specifically through dynamic intermittent activities such as moderate strength training and Nordic walking and water therapy [38]. Lack of studies and therefore an urgent need of research exist in the field of physical activity and advanced breast cancer, as medical treatment options have improved not only in curative care but also in palliative care. Therefore, patients suffering from advanced breast cancer tend to live for longer with their disease. The quality of life during this ex- tended period of survival may be improved through physical activity. According to current research, regular physical activity should not only be recommended but seems necessary with this patient group. The primary aim is to maintain functional mobility as long as possible. However, only few studies can be found, and therefore the evidence is weak. Current exercise recommendations are based on expert opinion. Due to the high number of patients with advanced breast cancer, there is a strong need to conduct future studies in this field of research in order to develop evidence-based guidelines.

Future research needs to examine specific and optimal exercise modes in terms of intensity and volume in order to achieve the best possible effect. Despite the above-mentioned positive effects of regular physical activity, most cancer patients during aftercare are not sufficiently active. Observations show that many survivors fail to reach the level of activity they had prior to their cancer diagnosis. Physical activity levels decrease significantly during the course of disease. Generally, they then increase again but often do not reach the original level [49, 50].

Despite the numerous studies on the positive effects of physical activity, findings regarding specific designs and modes of exercise programs are not yet sufficient. In the future, intervention studies need to focus on exercise modes and dosage-response effects in order to figure out the optimal effect of physical activity on individual goals [9]. Which exercise mode and dosage is most effective during the different therapy phases remains uncertain. Within this context, future studies may specifically focus on variables such as mortality risk, lymphedema, and advanced breast cancer. Further research is necessary in order to support breast cancer patients immediately after diagnosis by offering specific therapeutic exercise programs. This would counteract physical inactivity, which in turn could prevent negative effects such as decreased cardiovascular performance and improve quality of life. Physical activity can therefore help reintegrate patients into daily routine, and work and family life.

\section{Disclosure Statement}

The authors declare that they have no conflict of interests.

\section{References}

1 Robert-Koch-Institut und Gesellschaft der epidemiologischen Krebsregister e. V. (GEKID): Krebs in Deutschland 2007/2008 - Häufigkeiten und Trends. Berlin, 2012, pp. 64-67.

2 Shah C, Vicini FA. Breast cancer-related arm lymphedema: incidence rates, diagnostic techniques, optimal management and risk reduction strategies. Int J Radiat Oncol Biol Phys. 2011; 81(4): 907-14
3 Corner J, Wagland R, Glaser A, Richards SM. Qualitative analysis of patients' feedback from a PROMs survey of cancer patients in England. BMJ Open 2013; 10; 3(4)

4 Blanchard CM, Cokkinides V, Courneya KS, Nehl EJ, Stein K, Baker F. A comparison of physical activity of posttreatment breast cancer survivors and noncancer controls. Behav Med. 2003; 28(4): 140-149
Baena-Cañada JM, Estalella-Mendoza S, GonzálezGuerrero M, Expósito-Álvarez I, Rosado-Varela P, Benítez-Rodríguez E. Influence of clinical and biographical factors on the quality of life of women with breast cancer receiving adjuvant chemotherapy. Rev Calid Asist $2011 ; 26(5)$ :299-305

6 Stan D, Loprinzi CL, Ruddy KJ. Breast cancer survivorship issues. Hematol Oncol Clin North Am. 2013 Aug;27(4):805-2 
7 Hayes S, Spence R, Galvão D, Newton R: Australian Association for Exercise and Sport Science position stand: optimising cancer outcomes through exercise. J Sci Med Sport 2009;12:428-434.

8 Schmitz K, Courneya K, Matthews C, DemarkWahnefried W, Galvao D, Pinto B, Irwin ML, Wolin KY, Segal RJ, Lucia A, Schneider CM, von Gruenigen VE, Schwartz AL; American College of Sports Medicine: American College of Sports Medicine roundtable on exercise guidelines for cancer survivors. Med Sci Sports Exerc 2010;42:1409-1426.

$\checkmark 9$ Baumann FT: Physical exercise programs following cancer treatment. Eur Rev Aging Phys Act; DOI: 10.1007/s11556-012-0111-7.

10 Winningham ML, MacVicar MG: The effect of aerobic exercise on patient reports of nausea Oncol Nurs Forum 1988;15:447-450.

11 Winningham ML, MacVicar MG, Bondoc M, Anderson JI, Minton JP: Effect of aerobic exercise on body weight and composition in patients with breast cancer on adjuvant chemotherapy. Oncol Nurs Forum 1989;16:683-689.

12 Mock V, Pickett M, Ropka M, Muscari Lin E, Stewart KJ, Rhodes VA, McDaniel R, Grimm PM, Krumm S, McCorkle R: Fatigue and quality of life outcomes of exercise during cancer treatment. Cancer Pract 2001;9:119-127.

13 Courneya KS, Segal RJ, Mackey JR, Gelmon K, Reid RD, Friedenreich CM, Ladha AB, Proulx C Vallance JK, Lane K, Yasui Y, McKenzie DC: Effects of aerobic and resistance exercise in breast cancer patients receiving adjuvant chemotherapy: a multicenter randomized controlled trial. J Clin Oncol 2007;25:4396-4404.

14 Hwang J, Chang H, Shim Y, Park W, Park W, Huh S, Yang J: Effects of supervised exercise therapy in patients receiving radiotherapy for breast cancer. Yonsei Med J 2008;49:443-450.

15 Schwartz AL, Winters-Stone K: Effects of a 12month randomized controlled trial of aerobic or resistance exercise during and following cancer treatment in women. Phys Sportsmed 2009;37:1-6.

16 Mutrie N, Campbell A, Whyte F, McConnachie A, Emslie C, Lee L, Ritchie, D: Benefits of supervised group exercise programme for women being treated for early stage breast cancer: pragmatic randomised controlled trial. BMJ 2007;334:517.

17 Kim C, Kang D, Smith B, Landers K: Cardiopulmonary responses and adherence to exercise in women newly diagnosed with breast cancer undergoing adjuvant therapy. Cancer Nurs 2006;29:156165 .

18 Battaglini C, Mihalik J, Bottaro M, Dennehy C, Petschauer M, Hairston L, Shields, E: Effect of exercise on the caloric intake of breast cancer patients undergoing treatment. Braz J Med Biol Res 2008;41:709-715.

19 Mock V, Dow, K, Meares C, Grimm P, Dienemann J, Haisfield-Wolfe M, Quitasol W, Mitchell S, Chakravarthy A, Gage I: Effects of exercise on fatigue, physical functioning, and emotional distress during radiation therapy for breast cancer. Oncol Nurs Forum 1997;24:991-1000.

20 Yang C, Tsai J, Huang Y, Lin C: Effects of a homebased walking program on perceived symptom and mood status in postoperative breast cancer women receiving adjuvant chemotherapy. J Adv Nurs 2011;67:158-168.
21 Payne J, Held J, Thorpe J, Shaw H: Effect of exercise on biomarkers, fatigue, sleep disturbances, and depressive symptoms in older women with breast cancer receiving hormonal therapy. Oncol Nurs Forum 2008;35:635-642.

22 Pinto B, Frierson G, Rabin C, Trunzo J, Marcus B: Home-based physical activity intervention for breast cancer patients. J Clin Oncol 2005;23:35773587.

23 Vallance K, Courneya K, Plotnikoff R, Yasui Y, Mackey J: Randomized controlled trial of the effects of print materials and step pedometers on physical activity and quality of life in breast cancer survivors. J Clin Oncol 2007;25:2352-2359.

24 Hutnick N, Williams N, Kraemer W, Orsega-Smith E, Dixon R, Bleznak A, Mastro A: Exercise and lymphocyte activation following chemotherapy for breast cancer. Med Sci Sports Exerc 2005;37:18271835.

25 Ohira T, Schmitz K, Ahmed R, Yee D: Effects of weight training on quality of life in recent breast cancer survivors: the Weight Training for Breast Cancer Survivors (WTBS) study. Cancer 2006; 106:2076-2083.

26 Winters-Stone KM, Dobek J, Nail LM, Bennett JA, Leo MC, Torgrimson-Ojerio B, Luoh SW, Schwartz A: Impact + resistance training improves bone health and body composition in prematurely menopausal breast cancer survivors: a randomized controlled trial. Osteoporos Int 2013;24:1637-1646.

27 Sprod L, Drum S, Bentz A, Carter S, Schneider C: The effects of walking poles on shoulder function in breast cancer survivors. Integr Cancer Ther 2005;4:287-293.

28 Culos-Reed, S, Carlson, E, Daroux, L, HatelyAldous S: A pilot study of yoga for breast cancer survivors: physical and psychological benefits. Psychooncology 2006;15:891-897.

29 Ibrahim E, Al-Homaidh A: Physical activity and survival after breast cancer diagnosis: meta-analysis of published studies. Med Oncol 2011;28:753765.

30 Beasley J, Kwan M, Chen W, Weltzien E, Kroenke C, Lu W, Nechuta SJ, Cadmus-Bertram L, Patterson RE, Sternfeld B, Shu XO, Pierce JP, Caan BJ: Meeting the physical activity guidelines and survival after breast cancer: findings from the after breast cancer pooling project. Breast Cancer Res Treat 2012;131:637-643.

31 Cadmus BL, Stefanick M, Saquib N, Natarajan L, Patterson R, Bardwell W, Flatt SW, Newman VA, Rock CL, Thomson CA, Pierce JP: Physical activity, additional breast cancer events, and mortality among early-stage breast cancer survivors: findings from the WHEL Study. Cancer Causes Control 2011;22:427-435.

32 Friedenreich C, Gregory J, Kopciuk K, Mackey J, Courneya K: Prospective cohort study of lifetime physical activity and breast cancer survival. Int J Cancer 2009;124:1954-1962.

33 Holmes M, Chen W, Feskanich D, Kroenke C, Golditz G: Physical activity and survival after breast cancer diagnosis. JAMA 2005;293:24792486.

34 West-Wright C, Hederson K, Sullivan-Halley J, Ursin G, Deapen D, Neuhausen S, Reynolds P, Chang E, Ma H, Bernstein L: Long-term and recent recreational physical activity and survival after breast cancer: the California Teachers Study. Cancer Epidemiol Biomarkers Prev 2009;18:28512859

35 Loprinzi P, Cardinal B, Winters-Stone K, Smit E, Loprinzi C: Physical activity and the risk of breast cancer recurrence: a literature review. Oncol Nurs Forum 2012;39:269-274.

36 Mc Kenzie D, Kalda A: Effect of upper extremity exercise on secondary lymphedema in breast cancer patients: a pilot study. J Clin Oncol 2003;21: 463-466.

37 Schmitz K, Ahmed R, Troxel A, Cheville A, Smitz R, Grant L, Bryan C, Williams-Smith C, Greene Q: Weight lifting in women with breast cancer-related lymphedema. N Engl J Med 2009; 361:644-673.

38 Fernandez-Lao CC, Cantarero-Villanueva I, ArizaGarcia A, Courtney C, Fernandez-De-Las-Penas C, Arroyo-Morales M: Water versus land-based multimodal exercise program effects on body composition in breast cancer survivors: a controlled clinical trial. Support Care Cancer 2013;21:521-530.

39 Cavanaugh KM: Effects of early exercise on the development of lymphedema in patients with breast cancer treated with axillary lymph node dissection. J Oncol Pract 2011;7:89-93.

40 Headley J, Ownby K, John L: The effect of seated exercise on fatigue and quality of life in women with advanced breast cancer. Oncol Nurs Forum 2004;31:977-983.

41 Dimeo F, Stieglitz RD, Novelli-Fischer U, Fetscher S, Keul J: Effects of physical activity on the fatigue and psychologic status of cancer patients during chemotherapy. Cancer 1999;85:22732277.

42 Crevenna R, Schmidinger M,.Keilani M, Nuhr M Fialka-Moser V, Zettinig G, Quittan M: Aerobic exercise for a patient suffering from metastatic bone disease. Support Care Cancer 2003;11:120 122.

43 Loprinzi P, Cardinal B: Effects of physical activity on common side effects of breast cancer treatment. Breast Cancer 2012;19:4-10.

44 Kirshbaum M: A review of the benefits of whole body exercise during and after treatment for breast cancer. J Clin Nurs 2006;16:104-121.

45 McTiernan A: Mechanisms linking physical activity with cancer. Nat Rev Cancer 2008;8:205-211.

46 Brittenden J, Heys SD, Ross J, Eremin O: Natural killer cells and cancer. Cancer 1996;77:1226-1243.

47 Jakóbisiak M, Lasek W, Gołab J: Natural mechanisms protecting against cancer. Natural mechanisms protecting against cancer. Immunol Lett 2004;90:103-122.

48 Knop K, Schwan R, Bongartz M, Bloch W, Brixius K, Baumann F: Sport and oxidative stress in oncological patients. Int J Sports Med 2011; 32:960-964.

49 Devoogdt N, Kampen M, Geraerts I, Coremans T, Fieuws S, Lefevre J, Philippaerts R, Truijen S, Neven P, Christiaens MR: Physical activity levels after treatment for breast cancer: one-year followup. Breast Cancer Res Treat 2010;123:417-425.

50 Kwan M, Sternfeld B, Ergas I, Timperi A, Roh J, Hong CC, Quesenberry CP, Kushi LH: Change in physical activity during active treatment in a prospective study of breast cancer survivors. Breast Cancer Res Treat 2012;131:679-690. 